\title{
HASE YUUKI'S PERSONALITY MYTH IN ANIME FILM ISSHUUKAN TOMODACHI BY SHOUSUKE MURAKAMI
}

\author{
Yulia Sofiani Zaimar; Sugianti Somba \\ Universitas Indraprasta PGRI \\ Jakarta, Indonesia \\ Oleel27@gmail.com, sombacute08@gmail.com
}

\begin{abstract}
In this research, the researcher will examine Japanese animated films, Isshuukan Tomodachi. Isshuukan Tomodachi is a film that aired on February 18, 2017. The film was directed by Shousuke Murakami. Actualy, this anime film,taken for manga. The researcher is intrested in this film, because he sees many keys, how tobe a good friend. This research will be exposing the psychological of the main character, Hase through signs. Those signs would find out the hidden meaning behind the text (myth). The researcher choses Isshuukan Tomodachi to be researched, because it has excellent story quality and has elements of drama and romance combined nicely, because what is at the heart of the story is the complexity of the human heart itself in accepting the situation within itself, being honest with its own feelings, and the strength of friendship. As the result, many people are very difficult to make friends. The reason is not about arogancy. The results of this research, through the signifier and signified, show that Hase has an id that is not as big as the ego and superego. Hase can suppress the id so as not to get bigger and control himself Hase, which he shows by leaning on Kaori's father. This will be the foundation of analyzing.
\end{abstract}

Keyword: anime, film, sign, semiotic, psychoanalysis

\section{INTRODUCTION}

In this research, researchers will examine Japanese animated films. Film is one type or genre in literature, like: drama, process, and poetry that present fictional forms of stories, in different dimensions. Literature can also be said to be a description of the reality that uses language as a tool and a link between literary authors and literary connoisseurs, so that the values that the author imparts in a literary work can be conveyed to the audience. This is in line with the opinion expressed by Wibisono (2017: 57), which states that one of the communication tools often used by humans is to use language. So that a literary work can be used as a form of communication between authors and connoisseurs of literature.

Film is said to be a form of literary work because it uses language as a bridge to more vividly convey ideas, ideas, or values to the audience In this regard, Trianton (2013: 1) argues that "Films are the result of the creative process of filmmakers, which combines various elements such as ideas, value systems, views of life, beauty, norms, human behavior, and technological sophistication". Films are literary works that serve as a 
medium of communication and dissemination information. Films are able to convey information and messages in a literary work in a creative and unique way.

Films, including anime is a literary work of narrative, which can be analyzed with various approaches. Japanese animation, which is known as anime, is also a product of literary works. A literary work can be said to have literary value if it contains enjoyment and benefits, with a good and beautiful language form, and the arrangement of words and their contents can cause feelings of emotion and admiration in the hearts of the reader. This is also said by Endraswara (2003: 96), that "Literary work is the creation of a psychological process and the author's thoughts are in a subconscious situation, which is then poured into the form of a conscious situation".

Isshuukan Tomodachi is a film that aired on February 18, 2017. The film was directed by Shousuke Murakami. The story in this film, is a change from the manga with the same title by Matcha Hazuki, wrote on January 21, 2012. (https://aminoapps.com/c/anime/page/blog/ anime-review-isshuukanfriends/ZZtB_u5bb7ld1oxNNgLxPxqDWx 353P) Isshuukan Tomodachi tells about the life of school students upper middle. Hase Yuuki, who had just entered his second year of high school in the spring, had been watching Fujimiya Kaori since first grade. While in the library Hase saw his library card Kaori. Hase, who had been interested in Kaori for a long time, kissed the card and was caught by Kaori, and from there began Hase's struggle to be friends with Kaori especially in the second year they were in the same class.Kaori was always alone and chose not to have friends, Hase trying to be close and become Kaori's friend but Kaori always avoided, the reason Kaori did not have friends was finally revealed, it was all because Kaori had a disease where her memories of friends would just disappear on Mondays every week. Hase did not give up even though he had to repeat his friendship with Kaori, until Hase had an idea for Kaori, by changing the diary to recover Kaori's memory.

It has been told, that the source in this research is a Japanese film, titled Isshuukan Tomodachi by Shosuke Murakami. This story begins, when a high school student, Yuuki Hase begs a girl to make him a friend. Sadly, the girl said that she was happy, but she couldn't. With tears in her eyes, the girl then ran away from him. Hase just froze with a thousand question marks. Then, the next day, Hase saw Fujimiya being cold towards his friend who asked him to give the math teacher the book. In fact, Fujimiya is the class 
representative for maths lessons. This irritated his friend at Fujimiya's coldness. The researcher would like to analyzes the Isshuukan Tomodachi film from a psychological perspective, which is collaborated with Roland Barthes' semiotic approach. The researcher's interest in using literary psychology is in the human problem that depicts the psychological picture of the characters in the film. For previous research, this kind of research has also been analyzed by Ayuk Silvia Hariyanti, Yuliani Rahmah, Zaki Ainul Fadli, entitled: Konflik Batin Tokoh Akira Sakamoto. On this research, the difference with this research is that the research conducted by the researcher does not only discuss the personality of the characters. This research will be exposing it through sign, to find out the hidden meaning behind the text (myth).

Then, through semiotics, the psychological image can be analyzed through signifier and signified. The reason the writer examined the character Hase Yuuki, is because this main character has a personality that is very different from his friends at school. Therefore, the writer uses psychoanalytic theory combined with semiotics to explain more deeply how the personality is owned Hase Yuuki. Based on the above background, the problems to be discussed can be formulated in the question: how are markers and markers able to dissect Hase Yuuki's personality? Based on the formulation of the problem above, this research has a goal to be achieved, namely: Describing the personality structure of the character Hase Yuuki in the film Isshuukan Tomodachi, through signifier and signified. The researcher choses Isshuukan Tomodachi to be reseached, because it has excellent story quality and has elements of drama and romance combined nicely, because what is at the heart of the story is the complexity of the human heart itself in accepting the situation within itself, being honest with its own feelings, and the strength of friendship. The researcher is interested in this study, because she sees that not all people who find it difficult to make friends are arrogant, like many people thought. This will be the foundation of analyzing.

In describing the psychicology of the main character in this anime, the phisic battle is a conflict between the impulses, the conscious and the unconscious. This can be classified into three parts. This kind of splitting the mind into three parts is not intended to use a topographical model, but it can help explain mental images by function and purpose. Freud, his name is in fact very closely related to psychoanalysis, one of the most famous personalities. What makes Freud's theory so interesting? This is 
assumed, because the two foundations of psychoanalysis, namely sex and aggression, are two things that continue to be popular. Second, by his enthusiastic followers as well as loyal, that some of them consider. Then, in Feist and Gregory J. Feist (2010, 19) also explain that "Freud's language skills make his presentation of his theory so inspiring and lively".

Relating this, Endraswara (2008: 16) explains, that Literary psychology is an interdisciplinary between psychology and literature. From the quote above, it can be explained that "Psychology is the study of human mental behavior and functions scientifically which, when associated with literary works, is closely related to various human behaviors with all its conflicts". The main character in this theory is Sigmund Freud. Freud argued that the life of the soul has three levels of consciousness, namely conscious, pre-conscious, and unconscious. This topography or awareness map is used to describe the element of consciousness in every mental event such as thinking and fantasizing. Until the 1920s, the theory of psychological conflict only involved the three elements of consciousness. Based on this, Freud introduced three other structural models, namely the id, ego, and superego. This new structure does not replace the old structure, but enhances the mental image especially in its function or purpose.
The ego or I are the only areas of the mind that have contact with reality. The ego develops from an infant id and becomes one's only source of communication with the outside world. The ego is controlled by the reality principle, which tries to replace the id's pleasure principle. As the only realm of the mind connected with the outside world, the ego also takes on the role of the executive or decision maker of the personality. However, because the ego is partly conscious, partly subconscious, and partly unconscious, it can make decisions at all three levels.

The connotation is the meaning that is interpreted through the combination of markers with various cultural aspects that are broad in scope and also closely related to the beliefs of a person who interprets a particular symbol. So the connotation can be very multi-interpretation depending on each person who interprets it. So, in the Barthes concept there is a connotative sign which not only has an additional meaning, but also contains both parts of the denotative sign which underlies its existence. In fact, this is Barthes's very significant contribution to the perfection of Saussure's semiology, which stops at denotative sign. Damajanti (2006: 90) provides an understanding that psychoanalysis is a comprehensive system in psychology that Freud slowly developed 
when he handled people who experienced neurosis and other mental problems. Furthermore, Damajanti (2006: 90) also argues, that "Psychoanalysis presents a theory of how individuals function in personal relationships and in society". From this statement, the researcher saw the threads of the theory put forward by Freud and Barthes, to examine this anime film.

Besides sign, the researcher would also like to research the hidden meaning in the Hase character. In this part, the researcher would like myth by Barthes. In the myth there are also three-dimensional patterns of markers, markers, and signs. However, as a unique system, myth is built by a pre-existing chain of meaning or in other words, myth is also a second level meaning system. In the myth too, a sign can have several markers. When considering a news or report, it becomes clear that linguistic, visual signs and other kinds of signs regarding how the news is represented, such as layout, rubrics etc., are not as simple as denoting something, but also creates the level of connotation attached to the sign. Barthes $(2004,152)$ calls this phenomenon - carrying its signs and connotations to share certain messages - as the creation of myths. The definition of myth here does not refer to myth in the general sense of society, as is the case with folk tales. However, myth in Barthes' thought $(2004,152)$ is a way of meaning. In Barthes' thought, myth is a type or object model of a conversation or object of research. For Barthes, myth is a way of thinking from a culture about something, a way to conceptualize or understand something. Barthes in Fiske, 2007: 120123 ) asserts that the main workings of myth are there to naturalize history. Myth according to Barthes as a person's type of speech. In myth it is possible for a signifier to have many signified, for example sadness can have many signs.

\section{METHOD}

This research method uses a descriptive qualitative approach that is descriptive. Analytical data with all its rich meanings are as close as possible to the form of the recording or transcript, the meaning is only to describe a situation or event. According to Bogdan and Taylor in Moeleong (2002: 3) what is meant by qualitative research is a research procedure that uses descriptive data, in the form of written words or answers from people and observed behavior. A qualitative approach is a process of research and understanding, which is based on a methodology that investigates social phenomena and human problems. In this approach, the researcher creates a complex picture, examines words, reports in detail from the viewpoint of the 
respondent, and conducts studies on natural situations (Creswell, 2002: 136). Data analysis techniques are data reduction, data display, and data conclusion.

This research looks for facts using the right interpretation, with the aim of making descriptions, descriptions systematically, factually, and accurately about the meanings and signs in a film, so that the researcher uses the interpretive research type with a qualitative approach. The interpretive objective is to analyze social reality and how social reality is formed. Through qualitative research, researchers can identify subjects and feel what they experience in everyday life.

It has been told, that this reseach would combine semiotic and psychoanalysis. In order to have a better understanding about the psychological condition of the main character in this anime, the semiotic interpretation of signs can guide you to get the message or idea that anime films are trying to convey, as well as understanding the conditions. The following is a theory about Barthes' semiotics which is more familiar with various signs. Barthes (1977: 17) writes "by using the media in semiotics that in all these imitation arts there are two messages: denotative messages, namely analogues" Barthes wrote that analogons are representatives of objects, actually in the image which does refer to the object, the perception of reality and the image) itself, and the connotative message is the way how the audience to a certain extent communicates what they think about the message.

Looking at the history of this science of signs, the term which is always confusedis 'semiotics', but these two terms have the same analysis, namely the study of the science of signs. Obviously the term has its roots in the Greek semeio. According to Sebeok, sometimes the two terms are used to identify "the two semiotic traditions". The linguistic traditions of Saussure and Barthes are usually referred to as semiology. The Peirce and Morris tradition is referred to as semiotic. Nowadays, the term semiotics, generally more accepted, is also a synonym of semiology, which is also a branch of semiotics itself. Referring to modern semiotics, Saussure is one of the main figures besides Peirce for example. In addition to Saussure's first study of sign science, which is decades apart from Peirce's, he is also distinguished by his very strong focus on linguistics or linguistics. In simple terms, it can be said that Saussure is a formal semiotics or more on the 'pragmatic definition of meaning', which expresses the meaning in terms of its effectiveness. 
In semiotic analysis, Saussure and Barthes still use the term signifier-signified, which Saussure promotes. Barthes also saw another aspect of signification, namely "myth" which marks a society. "Myth" according to Barthes lies at the second level of signification, so after the sign-signifiersignified system is formed, the sign will become a new marker which then has a second marker and forms a new sign. So, when a sign which has a connotative meaning develops into a denotative meaning, the denotation meaning will become a myth. For example: A shady and dense banyan tree has the connotation of sacred, because it is considered a dwelling place for spirits. The connotation of "sacred" then develops into a general assumption attached to the symbol of the banyan tree, so that the sacred banyan tree is no longer a connotation but turns into a denotation at the second level of meaning, like chart below.

\begin{tabular}{|l|l|}
\hline $\begin{array}{l}\text { Sr. } \quad \text { (signifier) } \\
\text { rhetoric }\end{array}$ & $\begin{array}{l}\text { Sd. (signified) } \\
\text { Conotative }\end{array}$ \\
\hline Sr.(signifier) & \\
Sd(signified) \\
\cline { 1 - 1 } $\begin{array}{l}\text { Sr. (signifier) Sd. } \\
\text { (signified) Denotative }\end{array}$ \\
\hline
\end{tabular}

From chart, it would be explains, that semiology underlies Barthes studies then on the real objects or cultural elements that he often researches. The scope of cultural studies of Barthes is very broad. The study covers literature, film, clothing and various other cultural phenomena. Roland Barthes in Kurniawan (2001, 52) states that at least they are all signs. In his own language Barthes in Kurniawan (2001, 53) concludes that: "The world is full of signs, but these signs do not all have the fine simplicity of the letters of the alphabet, of highway signs, or of military uniforms: They are infinitely more complex. ". Meanwhile, at the level of meaning, the second layer is connotation. Meaning can be created by combining markers with broader cultural aspects such as beliefs, attitudes, frameworks and ideologies of a particular social formation.

\section{DISCUSSION}

Anime is a kind of modern Japanese literary works, that is not less popular than manga and cosplay. Since the 1990s, Indonesia has been treated to Japanese Popular Culture through television media. Anime products, which were aired on tv in the 1990s are Doraemon, Sinchan, etc. Anime that is served on television seems to have been well received in Indonesia since its inception in the 1990s. Anime 
enthusiasts in the Japanese anime market are always increasing, and again anime is not only popular in Japan. However, this anime itself is also quite popular in East Asia and Southeast Asia. For now, almost all over the world, anime lovers can be found themselves.

Isshuukan Friends means Friends of a week. As the title suggests, this anime tells of a friendship whose time is limited to one week. That's what happened to Fujimiya Kaori. Fujimiya Kaori, a flatfaced girl who is always alone. He did not have any friends and did not seem to want to be friends with anyone. This anime film was shown for a long time. This story is packaged in 12 episodes. For 12 episodes, the directed Tarou Iwasaki used him to build the story of Yuuki and Kaori's relationship slowly at the beginning. In this section you will see the daily lives of the two main characters and how they interact with each other. This story begins, by telling the beginning of their meeting colored with light humor and various special spices that exist in various stories of teen dramas. Not only that, the good acting performed by Kento and Haruna also succeeded in making the audience familiar with their characters. This portion of the two supporting characters appearance, Yuuki, Shougo, the genius who likes sleeping in class.
During breaks, Fujimiya always went to the roof of the school building to eat alone. Fujimiya's day at school caught the attention of Hase Yuuki, who was always watching him. Hase is interested in becoming friends with Fujimiya. When trying to talk to Fujimiya for the first time, Fujimiya responded coldly. Fujimiya tried to avoid Hase, not wanting to be her friend. Hase didn't give up. She kept trying to interact with Fujimiya. Until he went to the roof of the school, accompanying Fujimiya during his break. So every day. And finally, Kaori Fujimiya began to open his heart to Hase. Fujimiya started showing a smiling face.

\section{Signifier}

Hase Yuuki, who has a strong desire to be Kaori's friend, thinks of how to befriend Kaori. While his teacher was teaching, Hase found a way to befriend Kaori. The idea was to exchange diary books with Kaori. Hase's journey to become friends has many obstacles, starting from the homeroom teacher, Kaori's parents, and Kaori herself. The appearance of a new male student who is in the same class as Hase and Kaori also makes it difficult to achieve his wish. All these obstacles made Hase is starting to be worried. From this part, Hase is described as a clever character, because Hase has an idea that other people 
don't think of to be Kaori Fujimiya's friend. It can be considered as signifier.

\section{Signified}

Hase's persistence can be used as a sign of his ego, which wants Kaori as his friend.This thing can be seenin the picture below:

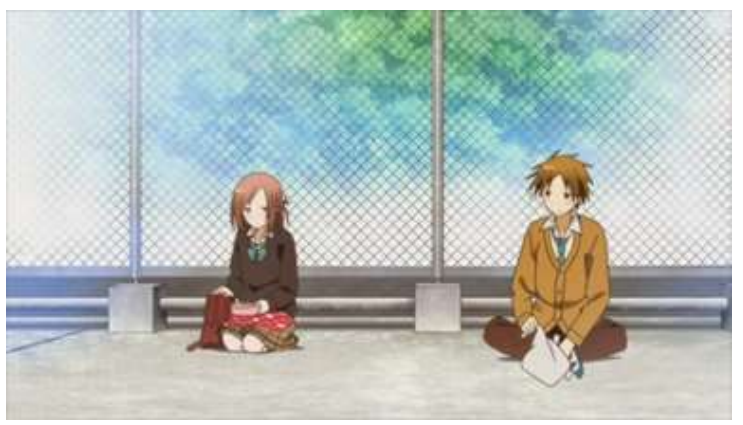

From the picture above, seeing Fujiyama sitting with a sad face can be a signifier, Fukiyama has a big problem in her. Then, seeing Hase faithfully sitting beside Fujiyama at a great distance was signified. From this scene, the myth that can be explained is that From the picture above, you can see Kaori finally opened her heart a little, and they were able to sit and chat together. At that time, Kaori gave a good response to Hase, when asked if they could be friends, it turned out that Kaori gave a good response, by wanting to be. Hase's friend. So that the two of them started getting close from then on.

Hase is depicted as a persistent character. Although, Fujiyama has always refused Hase's invitation to be friends, it can also be analyzed, that what Yuki Hase did can be analyzed as social support.
Social support is an action to provide emotional support when one of them is experiencing difficulties and needs a way out. Support is not only limited to giving material, it can also be in the form of hugs and positive advice. Social support is important because in friendship we must support each other in every situation.

Fujiyama always refuses suggestions from Hase, because she has a disease, where every Monday Kaori will forget the names of his friends and this makes Kaori reluctant to be his friend. Neverthless, what Kaori Fujiyama did, didn't make Hase just give up. Hase was still patient, when on Monday Kaori did not ask who Hase was, after they were together. This is contained in:

"I don't remember you at all. That probably means that you were my friend last week."

Therefore the signified, that Fujiyama refused Hase, because she hidessometing inside. It can beexplained in chart below:

\begin{tabular}{|l|l|}
\hline $\begin{array}{c}\text { Sr. (signifier) Kaori } \\
\text { never want to make } \\
\text { friends to anyone }\end{array}$ & $\begin{array}{c}\text { Sd. (signified) } \\
\text { ilness to anyone }\end{array}$ \\
\hline Sr.(signifier) & \\
\hline
\end{tabular}




\begin{tabular}{|l|}
\hline Hase aways tries to \\
get conversation to \\
Kaori \\
\hline Hase wonder, why \\
Kaori does that
\end{tabular}

From the chart, it can be seen that not all humans can share what is happening in themselves, ike Kaori. This is a form of anxiety. This can be proven by Sigmund Freud's statement in Alwisol (2008: 22). who argues that "Anxiety as a function of the ego to warn individuals about the possibility of a danger coming so that an appropriate adaptive reaction can be prepared. In the other hand, from this part, Hase is also described as a person who never gives up. Here the research, that Hase's ego become Fujiyama's friend is very strong playing in his mind. From the chart, the researcher can prove, by seeing Hase's determination to be Kaori's friend, it can be explained that the ego functions to channel the impulses of the subconscious into the real world. This is in line with what is explained by Jalaluddin (1996), who explains that "the mission carried by Ego in the individual is the principle of reality, such as objective or relative principle. All forms of instinctual drive from Id can only be realized in real form through assistance Ego. Which contains the principle of consciousness".

\section{Myth}

Previously we have found the meaning of Hase's wishes obtained from the first level of significance analysis, then we will continue the analysis of the second level of significance at the myth level. previously described, it will be deformed or transformed into a connotation signn at the mythical level. This film is a symbol of a conventional character contained in a symbol which signifies the meaning of friendship which is not only judged by the factor of closeness and togetherness. By using Barthes' approach which strengthens Freud's theory, friendship is mostly constructed using signs and sifnified, where in life there is an order of human values, conflict, without any betrayal. Hase's affection for Kaori was also shown in the scene, Hase's tears streamed down at Fujimiya. He then shouted and said that he was very stupid. This is, because Hase saw Kaori Fujiyama cry and said:

"I won't forget this day. I want to remember every second I spent with you today. Until the slighter. I don't want it more if I no longer be your friend !. If that day comes, even if I can remember you, I won't be happy., because I want to talk to you as much as I used to. I want us to be closer together. "

From analysis above, it can be explained, that the signified comes out, 
after we know the important position of linguistic messages in the process of significance, especially at the language level, how Yuki Hase approached Kaori Fujiyama, from the explanation above, the researcher tries to dig again the meaning at the mythical level of what Barthes has exemplified. Hase shading can also be seen in the image below:

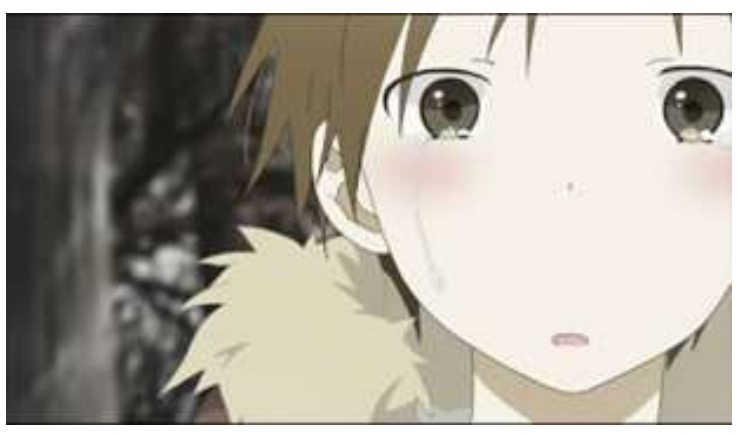

From this picture, we have obtained a unit. Reading or lexia are two of which are linguistic messages and the visual messages. From the picture above, there is a hint of regret in Hase's mind, because he saw Kaori's sadness. This is signified, that Hase sincerely loves Kaori. Love and kindness underlie friendship; these things will be difficult to lose from within humans. This friendship emphasizes what is best for our friends. It seemed that Hase remained patient, waiting for Kaori to talk to him. Friendship like this can be analyzed as the hidding massage in this film.

The process of delivering friendship messages in this research is depicted, when there is a an interaction between Yuki and Kaori characters in the film. In this scene,
Hase and Kaori describe an interpersonal relationship. Friendship is physical support where friendship provides time, abilities and help, such as when Hase covered Kaori's shortcomings, as in the quote:

Kujo: Just a coincidence. Even though, I was ignored by him.

Hase: Kaori?

Mayu: Is that so? It turns out it's not healed yet.

\section{Kujou: Cured?}

Hase: Talking about it is a bit sensitive.

Mayu: You know what?

Hase: Hey?

Mayu: About Kaori's memories

Kujou: What does that mean? (eps: 11)

From the quote above, it can be analyzed that friendship is ego support where friendship provides hope and support, encouragement and feedback that can help a person maintain an impression of him or herself as an individual who is capable of being attractive and valuable. Mutual trust cannot just come; it takes a process that takes place in a long time. From this scene it is also seen that the function of friendship is as a friend or companion, where friendship gives a a person, who is willing to spend time together. 


\section{CONCLUSION}

From the research of the Isshuukan Tomodachi, it can be concluded that Hase is a friend, who never gave up making Kaori smile. His sincerity had made Kaori Fujiyama's feelings melt, and makes her to tell him about what happen. Hase's character is able to reduce anxiety, which is experienced by Kaori. Through the signifier and the signified, it can be seen that Hase succeeded in sublimating Kaori's anxiety, through his ego to become a friend. The hidden meaning of never giving up on Hase, was also seen when Kaori's father opposed Kaori and Hase's friendship. In addition, this film also seems to convey that good friends are people who understand us and accept us as we are. In this story it can also be concluded that the result of Hase's selfishness can be detrermined. The myth of friendship that can be seen from the figure of Hase is that in life there are some people who need support from their closest people to become enthusiastic. In K Hase's figure, friendly relations will give someone a friend, who is truly loyal. That loyalty was shown, that Hase was willing to spend time together so that Kaori could recover from her illness.

This can be seen, when Hase ignored the request from Kaori's father. Hase keeps trying to be Kaori's friend. After Hase manages to maintain his friendship with Kaori, Hase tries to cover up Kaori's illness from his schoolmates. The ego that works based on reality embodies the desire of the id so that the ego tries to cover up Kaori's disease, so that it is not known by other people.

From the moment, that the character Hase hs aseen, how Hase try so hard to get Kaori's trust, and make her to be his friend. Therefore, It can be analyse, that the personality structure of Hase's character is not dominated by the id. The id that works on the basis of the pleasure principle can control the ego so that the ego is more likely to realize the desire of the id from at considering the superego which operates on the principle of morality. By being Kaori's best friend, Hase has been created as a person, who is abe to do good things, even he should determined his id, when he knows, Kaori's father does not allow him to be her friend.

From Kaori's side, this film will focus on her unique condition, where she will forget her friend every Monday. Then, we will see how Kaori will psychologically recover the efforts of Yuki Hase. However, from Yuki Hase's side, this film is an anime film, how a boy, who is able to fight for someone, whom he loves.

\section{REFERENCES}


Alwisol.(2008). Psikologi Kepribadian. Edisi Revisi. Malang : UMM Press.

Ayuk Silvia Hariyanti, Yuliani Rahmah, Zaki Ainul Fadli. (2016). Konflik Batin Tokoh Akira Sakamoto Dalam Manga Family Complex Karya Mikiyo. Sastra Jepang, Fakultas Ilmu Budaya, Universitas Diponegoro Jln. Prof. Soedarto, Tembalang, Semarang, 50239. diakses 15 Oktober 2020 dari http://ejournals1.undip.ac.id/index.php/ japliterature

Barthes, R. (1967). Elements of Semiology. London : Jonathan Cape.

Barthes, Roland. (1977). Image, Music, \& Text. Hill \& Wang

Barthes Roland. (2004). Mitologi. Terj. Nurhadi \& Sihabul Millah), Kreasi Wacana, Yogyakarta

Creswell, John W. (2002). Desain Penelitian. Jakarta: KIK Press.

Damajanti, Irma. (2006). Psikologi seni. Bandung: PT. Kiblat Buku Utama.

Endraswara, Suwardi. (2008). Metodologi Penelitian Sastra. Yogyakarta: Media. Pressindo

Feist, J. \& Gregory J. Feist. (2010). Teori Kepribadian (Edisi ketujuh). Jakarta: Penerbit Salemba Humanika

Jalaluddin. Rakhmat. (1996). Psikologi Komunikasi. Jakarta: Remaja Rosdakarya

Kurniawan. (2001). Semiologi Roland Barthes. Magelang: Yayasan Indonesia Tera.
Moeleong, L.J. (2002). Metodologi Penelitian Kualitatif. Remaja Rosdakarya. Bandung

Wibisono, Galih. (2017). "Pelanggaran Maksim Prinsip Kerja Sama Tokoh Utama Pada Film 梁祝 (Liang Zhu) Sampek Engtay" dalam Jurnal Cakrawala Mandarin, Jurnal Online Vol. 1 No. 2, diakses diakses 21 Oktober 2020 dari DOI (PDF): http://dx.doi.org/10.36279/apsmi.v2i2. $\underline{63 . g 35}$

https://aminoapps.com/c/anime/page/blog/a nime-review-isshuukan diunduh 16 Oktober 2020 friends/ZZtB_u5bb7ld1oxNNgLxPxqD Wx353 